\section{Genceral acmartis}

ON THE

\section{PRACTICE OF MEDICINE. \\ BY}

PETER MERE LATHAM, M.D.

\section{III.-CuRE.}

Cinchona: the Acceptance it first met with from Sydenham and his Contemporaries. Cure of Ague by it abolished Error, but taught no Truth respecting Processes of Recovery. Obligation to use Special Remedies in our Present State of Imperfect Knowledge.

I HAVE somewhere heard or read of the doctrine that every disease has its antidote; and that the proper specific remedy capable of curing it exists somewhere in the world, if we could but find it out; and that the Divine wisdom and mercy are pledged for such being the nature of things. This being admitted would at once render the search after new specifics our supreme duty. But I cannot follow the doctrine either with my head or with my heart. On the contrary, I conceive it hardly possible for a physician to employ his time worse than in quest of new specifics. His common sense would be about equal to that of the man who should trust his hopes of growing rich to the chance of finding a bag of money. But a specific medicine is an excellent thing, and so is a bag of money; and, being found, it is worth the study of a life to turn them both to all the good purposes of which they are capable.

Now it strikes one that we should be able to make a better use of specifics or special remedies if we knew more about them; if we could raise the curtain a little, and catch a glimpse of them at work in some positive manner; if we could discern them doing something conducive to the ultimate end for which we give them. I do not mean their modus operandi, but quite a different thing, and more important and more practical. I prescribe all my best non-specific remedies for the sake of certain immediate effects, promising myself through these effects to bring the disease to a favourable termination. But, in the meantime, I know nothing of their modus operandi in producing even the immediate effects for which I give them; and yet I continue to give them with as much confidence as if I knew all about it. How mercury makes the bile to flow, or how opium brings quiet and sleep, I do not know; but my experience trusts them for these effects; and these effects are in my hands preparatory to the successful management of many forms of disease.

To ask, then, about specifics, What is their modus operandi? is to put a question which has not yet been answered about the commonest and most useful remedies which we employ, being non-specifics.*

Cinchona cures one disease at all times, in all places, and in all men; and that disease is ague. As a specific for ague, it seems tied to no conditions. But, ever since cinchona has been the known specific for ague, all diseases that have borne the name of

* Quid scammoneæ rndix ad purgandum, quid aristolochia ad morsus serpentum, possit, video, quod satis est; cur possit, nescio. (Cicero, De Divinat, Lib. I.) fever, all that have had fever in any way annexed to them, have at some times, in some places, and in some men, been deemed curable and cured by it. And in these diseases it often does its work as cleanly and summarily as when it cures an ague. It seems now the same noble specific as then; but now it must surely be tied to conditions, if we could but make out what those conditions are.

There is a good deal about Peruvian bark in Sydenham, and the acceptance it met with at the hands of physicians a quarter of a century after its virtues were first heard of in English; and it is curious to note what manner of men Sydenham and his contemporary physicians were, as he represents them and himself sitting, as it were, in judgment upon the new remedy. And some of them were wise, and some were foolish, as physicians are now ; and the most foolish were those who were the wisest in their own conceit, as they are now. And then, as now, a really wise man would occasionally make shipwreck of part of his wisdom by venturing out of his depth and pretending to know more than possibly could be known.

Men died largely of agues before bark was given to cure them. For want of it, they displayed symptoms many and shocking enough the longer they lasted and went uncured. For these, Sydenham intimates, some physicians were on the watch; and no sooner was the bark given than they were ready to ascribe them to it forthwith, though the patient might have taken but a single dose of it.* Here was downright prejudice or wilful dishonesty. Others, and the most part of physicians, seeing the bark got rid of the disease by a secret virtue, and not by any sensible evacuation, would have it that the materies morbi was not got rid of at all, but that it was pent up and confined by the astringent power of the remedy, and thus only lay covert, like an enemy within walls, ready to begin new commotions. $\dagger$ This was to take measure of the truth by the standard of their own preconceptions, and believe Nature more likely to err doing her own work in her own fashion than doing it in theirs.

Elsewhere Sydenham alludes to the extravagance of theory and practice which had long prevailed touching intermittent fevers, and which in his time seems to have gone so far that it could not well go farther. "For how many ages," he remarks, "had the observant men been exercising their wits in search of the causes of these fevers; and so each adopted the practice best suited to the theory of his own excogitating. But how little these exploits of medicine served to prove the truth of their speculations was pretty evident from what was of recent memory, when they placed the various species of intermittents in various kinds of redundant humours, and then aimed at curing them by alteration and evacuation of the same. How unfortunate was the whole business, both theory and practice, their own failure showed; but above all the more successful use of the Peruvian bark, by means of which, he adds, we now-

* His autem potissimum de causis (nisi fallor) cortex malè audit: primo, quia plurima illa horreudaqua symptomata qua febres intermittentes jam diutius agrum cruciantes comituntur, etiam ubi ne minimum quidem corticis degustaverit, cortici vel semul assumpto imputantur. (Epist. I. Responsoria, 15.)

+ Secundo, quia cùm occultâ vi et non per sensibilem aliquam evacuationem morbum averruncet, statuunt plerique materiam morbum committentem quæ propelli debuerat, tanquam hostem intra mœnia vi corticis astringenti inclusam latere, novos daturam tumultus. (I bid.) 
a-days, turning topsy-turvy all notion of humours and regimen and diet, and everything of the kind, and, only looking to the right way of exhibiting the powder, aim directly at the mark, and hit it."*

But let not this brief allusion to the prejudices of past times touching the Peruvian bark be deemed altogether useless. Bark may be taken as the type of all specific remedies; and what though it and they are only to be simply given, and the disease simply ceases? What though it and they throw no direct light upon the nature of the diseases they cure, or upon their own way of curing them? Yet the indirect light which they contribute to all rational study of pathology and practice is considerable; and of this Sydenham was well aware, and ascribed to them a peculiar value on this account.

Sydenham believed (a curious fact) that there would some day be found out a specific for gout. Long thought upon the subject had, he tells us, brought him to that belief; and he adds, "should it ever be realised, it will rebuke the dogmatists for their ignorance, and show their extraordinary hallucinations in pretending to discriminate the essences of diseases, and in choosing remedies to compass their cure. Of this we have an instance clear enough in the discovery of that supreme specific for intermittent fever, the Peruvian bark." $\dagger$

The next best thing to seeing, knowing, and getting well hold of the truth, is to clear away impediments that block up the road which leads to it. This the Peruvian bark did for us two centuries ago, when first it was found a specific for intermittent fevers. In curing them, it disclosed nothing of their essence, and nothing of its own way of dealing with them. It simply swept them away; but, in so doing, it swept clean out of mind and remembrance many farfetched notions of them, their nature, and their cure, which by possibility could not be true. It removed notions which had usurped the place of efficient causes, but it did not substitute truths in their stead.

And now, after the lapse of two hundred years, what do we in our day think of this same Peruvian bark? Next to opium, we value it above all remedies in the world. But, after two hundred years, what more do we know of it? Of the thing itself we, indeed, know more, much more-even all, perhaps, that can be known. Peruvian bark was the first or nearly the first of vegetable substances used in medicine upon which chemistry essayed its power

\footnotetext{
* Per quot jam sæccula homines quique solertissimi ingenis exercuerant in investigandis harum febrium causis, quibus praxin quilibet aptavit theoriæ a se excogitatæ optime respondentem! Quomodo vero hæ medicationes theoremata valebant defendere, ex iis constat quorum adhuc recens est memoria, in quibus varias in. termittentium species in variis humoribus in corpore redundantibus collocantus, curationem ad humorum istorum nlterationem atque evacuationem dirigere solebant. At quam inauspicato id egerunt, eorum in his conaminum frustratio, præcipuè vero hujus corticis usus felicior, palam faciunt: cujus ope nos nunc temporis tum humores hujusmodi omnes, tum etiam diætam et regimen quodcunque, susque deque habentes, ac nihil nisi methodum pulveri exhibendo debitam observantes, scopum recta attingimus. (Tractatus de Podagrâ, 71 .

+ Non his majora promitto; quamvis a longâ cogitationum serie, quas huic rei impendere tantum non sum coactus, inducar credere ejusmodi remedium quandoque inventum iri. Quod si unquan acciderit, inscitian suam dogmaticis exprobabit, atque exinde liquebit quàm insigniter, tam in dignoscendis morborum esseutiis, quam in medicamentis quibus eos aggrediuntur, hallucinentur. Cujus rei exemplum satis luculentum habemus in repertione summi illius ad febres intermittentes specifici, Corticis Peruviani. (Tractatus de Podagrá, ri.)
}

of analysis, and seized and separated the simple element containing all its curative power. And not of the thing itself only, but also of its curative power, do we know more, infinitely more. And the one knowledge has led the way to the other; for mere grains of the simple element, quinine, were found curatively equivalent to scruples and drachms of the bark. And hence came the readier use of the remedy, and then its larger use ; and its larger use has rapidly multiplied our experience of its curative power. But neither scientific experiment upon the thing itself, nor trial of its remedial effects during two hundred years, has enabled us to catch a glimpse of it actually at work. It increases nothing, and diminishes nothing. It neither evacuates nor restrains. It has to do neither with bile, or with urine or saliva; nor with any special secretion. It neither directly soothes nor directly stimulates. It neither puts to sleep nor keeps awake. It works the cure; but it does nothing, as far as we see, prior, preparatory, and intermediate to the cure it works.

There are things in our living bodies which have never yet been reached or touched by human knowledge. Much of health and disease, of life and deatb resides in these things; and the means and instruments of health and disease, and of life and death, are largely concerned with them. What strengthens and weakens, what heals and injures, what preserves and destroys, even all food and all medicine, whether for good or harm, have their operation more or less in this region of things inscrutable. Our present business is with medicine; and even of the remedies which we understand the best, and choose according to rational indications, and are able to guide stage by stage in the work we wish them to do, there is not one which in the way to its accomplished purpose does not do something beyond or beside what we comprehend. We lose sight for awhile of it and its operations in this region of things inscrutable; we cannot follow it with a complete intelligence of what it does from first to last. But the remedies which fulfil their one and complete work of cure without show of doing anything whatever prior or conducive to it, ever specifics or special remedies, afford the surest conviction of a region of vital operations beyond the range and reach of our knowledge.

Yet we must not make our ignorance of how the special remedy cures a bar to our use of it. Our knowledge of all remedies, in the gradations and progress of their working, is incomplete; so that, after all, perhaps the most just distinction between specifics and cure on the one hand, and non-specifics and treatment on the other, would be, that of the former we know absolutely nothing but the bare result, and of the latter we know both the result and something of the way they travel to it. But this something may be very much or very little; yet, be it much or be it little, we are naturally proud of it. We prefer the implements which we in any measure guide by our eye and impel by the force of our right hand, to those which we must leave from first to last to their own self-working, and trust to bare experience for the result. But be it always remembered what is our calling. Human lives are given us in charge ; and so the amount and certainty of benefit within reach of the remedy may become grounds for its preference before any knowledge we have of the 
way in which that benefit comes to pass. It will not do to set up the conceit of a little philosopy against the moral obligation of doing good.

In medicine, this incrutable region is not only a pretty large one, but there is often as good reason for trust of things transacted therein it as of things done in more open day. And no disparagement of our profession is contained in this truth. A vast experience of results is needed as the groundwork of a sound faith in cure by specifics and special remedies; and surely such experience is a thing at least not opposed to knowledge.

Specifics or special remedies always seem to me to contain within them a promise or prophecy of future knowledge, waiting for time and opportunity and suitable minds to work it out. But, in the meanwhile, the results are so full of benefit to mankind, that they are allowed to have a premature accomplishment; and so wc are put in trust of them and their great power and mystery of doing good, and find ourselves able to use them aright upon the simple condition of a large general experience. But the work is greater than the workman. It must be so at present; and there is good reason to be content. It may take ages to bring out the explanation how bark cures an ague ; and the explanation, when it comes, may carry with it the discovery of new physiological truths. But these truths, known at last, may leave the practical uses of the remedy where they were. Thus, for wise ends, things seem to work in an inverted order; and the uses of knowledge take precedence of knowledge itself.

Curious Zoological Discoveries. When, some time ago, the telegraphic communication between Cagliari and Bona, in Algeria, was suddenly interrupted, after subsisting for the space of two years, measures were resorted to for the purpose of getting the cable up again, an operation which only succeeded partially. The portion of the cable recovered having laid in a submarine valley of the depth of from 6,000 to 8,000 feet, an excel. lent opportunity was thus offered for the study of the zoological species to be found at that depth. M. Alphonse Edwards, a French naturalist, who was on the spot at the time, has now published the results of his observations on that occasion. Among the extraneous bodies which adhered to the cable, he mentions several molluses still living at the time they were brought up. One of them was the ostrea cochlea, a kind of oyster which is frequent enough in the Mediterranean at a depth of from 300 to 400 feet, but which had never been found at any depth approaching to that of the valley above mentioned. It must have fixed itself to the cable when very young; for its lower valve, about six centimetres in breadth, had completely assumed the shape of the cable's surface like a plaster-cast. There was also a pecten opercularis, a sea shell, one of the valves of which fits like a lid on the other, attached to the cable, and a much rarer one also, the pecten testa. To these were added two gasteropodes, the monodonta lim. bata, and fusus tamedosus, both extremely rare, and containing the animal alive within. Of corals there were fourteen specimens belonging to three different species of the family of turbinolides, two of which are new ; and one fossil, that is hitherto only found in ancient geological strata, mixed with other palæonto. logical fragments. It has thus been ascertained beyond a doubt, that at a depth of 8,000 feet below the surface of the sea there exist living beings of sedentary habits, and mostly belonging to such species as have been very seldom found at more accessible depths.

\section{迎erture}

ON

\section{VESICO-VAGINAL AND RECTO- VAGINAL FISTULA.}

DELIVERED AT THE SAMARITAN IOSPITAL, MAY $21 \mathrm{TH}, 1861$.

$\mathrm{BX}$

T. SPEN CER W E L L S, F.R.C.S., SURGEON to The hospital.

[Concluded from page 252.]

The wires having been passed, the next thing is to

Unite the Pared Edges by Twisting the Wires. In the great majority of cases, this can be done by the fingers alone. Wire is not to be tied in a knot, like thread or silk; a simple twist is enough to fix it securely. Each end of a wire is taken between the thumb and second finger of each hand, and the forefingers are passed on close to the fissure, the edges of which are brought together by crossing the wire. When the edges are seen to lie close together, not so squeezed that they are inverted, but simply drawn evenly together, a slight turn with the forefingers gives the first twist. The fingers are here shown just about to give this twist $(a)$. Next (b) you see the twist complete, though the wire is opened out again to show the turn; and next (c), three or four turns have been made, and the ends of the wire cut off, thus completing the suture. (Fig. 13.) One after another, all the wires are so fast-

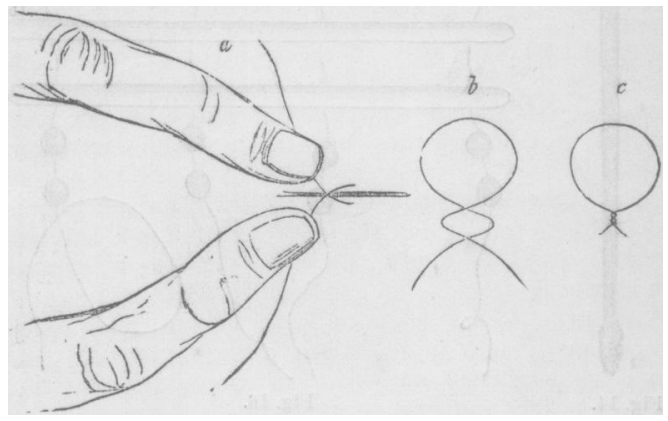

Fig. 13.

ened, and the ends cut off. This simple process fully answers the purpose in most cases. Where the fistula is so deep that the fingers do not reach easily, this instrument, Dr. Simpson's wire-twister, answers remarkably well. (Fig. 14.) There are two holes at the end of the shaft. One end of a wire is passed through one hole, the other end through the other hole, and the twister is then pushed on, while the wires are held tightly, till the edges of the opening are seen to be close together. Then two or three turns given to the handle fix the suture, as shewn in this larger view of the end. (Fig. 15.)

I believe this is all I really need say as to the mode of closing vaginal fistulæ; but the clamps of Sims, the button of Bozeman, and the splint of Simpson, have been so much talked about that, 